Review

\title{
Measures used for the evaluation of balance in individuals with Parkinson's disease: a systematic review
}

\author{
Jamile Benite Palma Lopes ${ }^{1)}$, Gileno Edu Lameira de Melo ${ }^{2)}$, Roberta Delasta Lazzari ${ }^{1)}$, \\ Cibele Almeida Santos ${ }^{1)}$, Renata Calhes Franco de Moura ${ }^{1)}$, \\ Arislander Jonathan Lopes Dumont ${ }^{1}$, Luiz Alfredo Ferreirra Braun ${ }^{3}$, \\ Natalia Almeida Carvalho Duarte ${ }^{1}$, Rodolfo Borges Pareira ${ }^{4)}$, \\ Isabela Marques Miziara ${ }^{5)}$, Claudia Santos Oliveira ${ }^{1)^{*}}$ \\ 1) Movement Analysis Lab, University Nove de Julho (UNINOVE): Rua Itapicuru, 380, Apto: 111, \\ Perdizes, CEP: 05006-000, São Paulo, Brazil \\ 2) Center of Biological Sciences and Health, State University Pará (UEPA), Brazil \\ 3) College Guaraicá and State University Midwest (UNICENTRO-PR), Brazil \\ 4) School of Postural and Manual Therapy, Salgado Institute of Integral Health, Paraná, Brazil \\ 5) Electrical Engineering College (FEELT), University of Uberlândia (UFU), Brazil
}

\begin{abstract}
Purpose] The present literature review was conducted on the use of different measures for the evaluation of balance in patients with Parkinson's disease. [Materials and Methods] The PubMed, Bireme, SciELO, Lilacs, and PEDro electronic databases were searched for relevant studies. [Results] The searches initially led to the retrieval of 3,623 articles, 540 of which were potentially eligible after limiting the search to clinical trials published in the last five years. A total of 264 duplicates were removed, and 276 articles were excluded based on their titles and abstracts. The full texts of 84 articles were analyzed, and only those with a PEDro score higher than four points $(\mathrm{n}=25)$ were included in the review. [Conclusion] Different methods, such as scales, tests, and equipment, are used for the evaluation of balance in patients with Parkinson's disease. More than one measure has been employed in most studies, and there is no consensus on a single precise measure for the evaluation of balance in this population. Key words: Parkinson's disease, Balance, Postural control
\end{abstract}

(This article was submitted Dec. 21, 2015, and was accepted Feb. 15, 2016)

\section{INTRODUCTION}

Parkinson's disease (Parkinson's) is a progressive, chronic, neurodegenerative disease ${ }^{1)}$ stemming from the atrophy of grey matter. It is estimated that 10 million individuals around the world suffer from Parkinson's, and this figure is expected to double by the year $2030^{2}$. The prevalence of Parkinson's ranges from $0.3 \%$ among individuals aged less than 60 years to $1 \%$ among those aged 60 or older ${ }^{3}$. The progressive nature of the disease causes both motor and non-motor alterations. The main motor alterations are associated with the risk of falls, which leads to a sedentary lifestyle and the reduction in activities of daily living exerts a negative impact on clinical aspects ${ }^{1-5)}$

The main clinical manifestations of Parkinson's are shaking, stiffness, slowness of movement, postural alterations, and stooped gait, leading patients to adopt a flexed posture due to the dominance of pro-gravitational muscles, with forward leaning of the head, the chin tlited toward the thorax, kyphotic thorax, protracted shoulders, the arms rotated internally, and, flexion of the hips, knees, and elbows, which projects the body forward, compromising postural orientation and leading to

\footnotetext{
*Corresponding author. Cláudia Santos Oliveira (E-mail: csantos@uninove.br)

(C)2016 The Society of Physical Therapy Science. Published by IPEC Inc.

This is an open-access article distributed under the terms of the Creative Commons Attribution Non-Commercial No Derivatives (by-nc-nd) License $<$ http://creativecommons.org/licenses/by-nc-nd/4.0/>.
} 


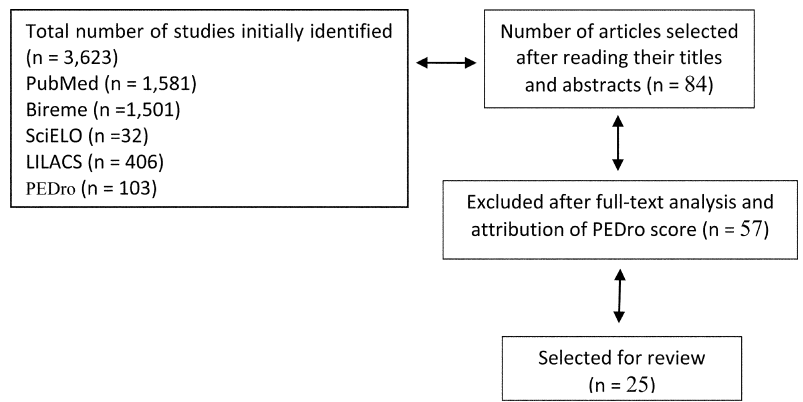

Fig. 1. Flowchart of studies included in the present literature review

impaired balance ${ }^{6}$. All these postural changes, together with other alterations, lead to postural instability, which is considered one of the main characteristics of patients with Parkinson's. This instability leads to a progressive reduction in both static and dynamic balance, affecting one's ability to remain standing without support or even sit down.

Researchers believe that postural instability is related to the loss of the capacity to control intentional movements of the center of body mass on the support base during activities that involve the transfer of weight. Many individuals with Parkinson's demonstrate inadequate interactions among the vestibular, visual, and proprioceptive systems, with consequent changes in the biomechanics of the body ${ }^{7}$.

The motor rehabilitation process for patients with Parkinson's is normally directed toward static and functional balance training to provide greater interactions with the surrounding environment through treadmill training ${ }^{8)}$, balance training involving virtual reality programs ${ }^{9}$, the combination of dance and motor training ${ }^{10)}$, etc. A set of assessment measures to determine the effects of particular interventions has been validated and reported in literature ${ }^{11)}$. Assessment measures are important for analysis of functional changes in all stages of the disease and are particularly sensitive with regard to the evaluation of therapeutic intervention ${ }^{12}$. The Unified Parkinson's Disease Rating Scale (UPDRS) ${ }^{13)}$, Berg Balance Scale, Timed Up and Go Test ${ }^{14)}$, Six-Minute Walk Test (6WMT), 10-Meter Walk Test (10MWT) ${ }^{15}$, and a force plate to determine the center of pressure ${ }^{16)}$ are among the measures used for the evaluation of balance. Moreover, a combination of different measures previously used in controlled clinical trials is often employed.

The aim of the present study was to perform a systematic review of the literature for the analysis of different measures used in the evaluation of balance in patients with Parkinson's disease.

\section{MATERIALS AND METHODS}

The PubMed (National Library of Medicine), BVS Bireme, SciELO, LILACS and PEDro electronic databases were searched for relevant studies addressing balance in patients with Parkinson's disease. For this purpose, the following combinations of keywords were used: Parkinson's disease and balance evaluation, Parkinson Disease and balance alterations, Parkinson Disease and balance change, Parkinson Disease and change in balance, Parkinson Disease and Balance Control and Parkinson Disease and Postural Control Balance. The search was limited to randomized controlled, clinical trials published in the previous five years (inclusion criteria).

The searches initially led to the retrieval of 3,623 articles, 540 of which were potentially eligible based on the inclusion and exclusion criteria. A total of 264 duplicates were removed, and 276 articles were excluded based on their titles and abstracts. The full texts of 84 articles were analyzed, with the inclusion of only those that met the eligibility criteria and had a PEDro score higher than four points. Thus, 25 studies were selected for the present systematic review (Fig. 1).

\section{RESULTS}

Table 1 displays the PEDro scores of the 25 studies that met the eligibility criteria and were included in the present systematic review. Diverse methods for the evaluation of balance in individuals with Parkinson's were used in studies with different intervention protocols and comparisons between the experimental and control groups (Table 2).

\section{DISCUSSION}

In the context of chronic neurological disorders, efforts are made to diminish physical difficulties and allow affected individuals to perform activities of daily living with the greatest possible efficiency and independence ${ }^{38)}$. Thus, assessment tools and specific measures that address more generic aspects, such as muscle strength, range of motion, functioning, and im- 


\begin{tabular}{|c|c|c|c|c|c|c|c|c|c|c|c|c|}
\hline \multirow[b]{2}{*}{ Reference } & \multicolumn{12}{|c|}{ Item } \\
\hline & 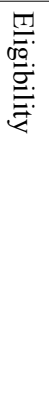 & 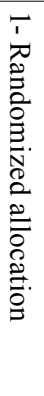 & 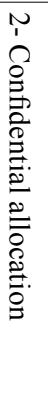 & 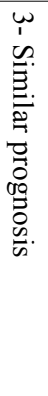 & 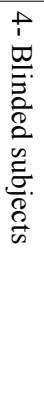 & 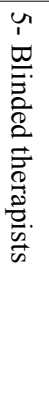 & 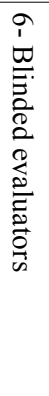 & 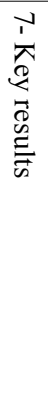 & 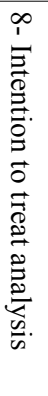 & 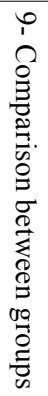 & 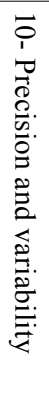 & $\begin{array}{l}\text { D } \\
0 \\
0 \\
0\end{array}$ \\
\hline Abud Qutubuddin et al., 2013 ${ }^{17)}$ & $\mathrm{Y}$ & $\mathrm{Y}$ & $\mathrm{N}$ & $\mathrm{Y}$ & $\mathrm{N}$ & $\mathrm{N}$ & Y & $\mathrm{N}$ & $\mathrm{N}$ & $\mathrm{Y}$ & $\mathrm{Y}$ & $5 / 10$ \\
\hline Sara Pires et al., 2014 ${ }^{18)}$ & $\mathrm{Y}$ & $\mathrm{Y}$ & $\mathrm{N}$ & $\mathrm{Y}$ & $\mathrm{N}$ & $\mathrm{N}$ & $\mathrm{Y}$ & $\mathrm{Y}$ & $\mathrm{N}$ & $\mathrm{Y}$ & $\mathrm{Y}$ & $6 / 10$ \\
\hline Chirs J., Hass et al., 2012 ${ }^{19)}$ & $\mathrm{Y}$ & $\mathrm{Y}$ & $\mathrm{N}$ & $\mathrm{Y}$ & $\mathrm{N}$ & $\mathrm{N}$ & $\mathrm{N}$ & Y & $\mathrm{Y}$ & $\mathrm{Y}$ & $\mathrm{Y}$ & $6 / 10$ \\
\hline Fuzhong Li et al., 2012 20 ) & $\mathrm{Y}$ & $\mathrm{Y}$ & $\mathrm{N}$ & $\mathrm{Y}$ & $\mathrm{N}$ & $\mathrm{N}$ & $\mathrm{Y}$ & $\mathrm{Y}$ & $\mathrm{Y}$ & $\mathrm{Y}$ & $\mathrm{Y}$ & $7 / 10$ \\
\hline Xia Shen et al., 2015 21 ) & Y & $\mathrm{Y}$ & $\mathrm{Y}$ & $\mathrm{Y}$ & $\mathrm{N}$ & $\mathrm{N}$ & $\mathrm{Y}$ & Y & $\mathrm{Y}$ & $\mathrm{Y}$ & $\mathrm{Y}$ & $8 / 10$ \\
\hline Natalie E., Allen et al., 2010 22 ) & $\mathrm{Y}$ & $\mathrm{Y}$ & $\mathrm{Y}$ & $\mathrm{Y}$ & $\mathrm{N}$ & $\mathrm{N}$ & $\mathrm{N}$ & $\mathrm{Y}$ & $\mathrm{N}$ & $\mathrm{Y}$ & $\mathrm{Y}$ & $6 / 10$ \\
\hline Emma Stack et al., 2012 23 ) & $\mathrm{Y}$ & $\mathrm{Y}$ & $\mathrm{Y}$ & $\mathrm{Y}$ & $\mathrm{N}$ & $\mathrm{N}$ & $\mathrm{Y}$ & $\mathrm{N}$ & $\mathrm{N}$ & $\mathrm{N}$ & $\mathrm{Y}$ & $5 / 10$ \\
\hline Xian Shen et al., 2014 ${ }^{8)}$ & $\mathrm{Y}$ & $\mathrm{Y}$ & $\mathrm{Y}$ & $\mathrm{Y}$ & $\mathrm{N}$ & $\mathrm{N}$ & $\mathrm{N}$ & $\mathrm{Y}$ & $\mathrm{Y}$ & $\mathrm{Y}$ & $\mathrm{Y}$ & $7 / 10$ \\
\hline C., Tassorelli et al., 2014 24$)$ & $\mathrm{Y}$ & $\mathrm{Y}$ & $\mathrm{Y}$ & $\mathrm{Y}$ & $\mathrm{Y}$ & $\mathrm{Y}$ & $\mathrm{N}$ & $\mathrm{Y}$ & $\mathrm{N}$ & $\mathrm{Y}$ & $\mathrm{Y}$ & $8 / 10$ \\
\hline Nima Toosizadeh et al., 2014 25 ) & $\mathrm{Y}$ & $\mathrm{Y}$ & $\mathrm{Y}$ & $\mathrm{Y}$ & $\mathrm{Y}$ & $\mathrm{N}$ & $\mathrm{N}$ & $\mathrm{Y}$ & $\mathrm{N}$ & $\mathrm{Y}$ & $\mathrm{Y}$ & $7 / 10$ \\
\hline Alessandro Picelli et al., 2012 26 ) & $\mathrm{Y}$ & $\mathrm{Y}$ & $\mathrm{N}$ & $\mathrm{Y}$ & $\mathrm{N}$ & $\mathrm{N}$ & $\mathrm{N}$ & $\mathrm{Y}$ & $\mathrm{N}$ & $\mathrm{Y}$ & Y & $5 / 10$ \\
\hline Nicola Smania et al., 2010 27 ) & $\mathrm{Y}$ & Y & $\mathrm{Y}$ & $\mathrm{Y}$ & $\mathrm{Y}$ & $\mathrm{Y}$ & $\mathrm{Y}$ & $\mathrm{Y}$ & $\mathrm{Y}$ & $\mathrm{Y}$ & $\mathrm{Y}$ & 10 \\
\hline Mohan Ganesan et al., 2014 28 ) & $\mathrm{Y}$ & $\mathrm{Y}$ & $\mathrm{N}$ & $\mathrm{Y}$ & $\mathrm{N}$ & $\mathrm{N}$ & $\mathrm{N}$ & $\mathrm{Y}$ & $\mathrm{Y}$ & $\mathrm{Y}$ & $\mathrm{Y}$ & $6 / 10$ \\
\hline José Eduardo Pompeu et al., 2012.,9) & $\mathrm{Y}$ & $\mathrm{Y}$ & $\mathrm{N}$ & $\mathrm{Y}$ & $\mathrm{N}$ & $\mathrm{N}$ & $\mathrm{Y}$ & $\mathrm{Y}$ & $\mathrm{N}$ & Y & $\mathrm{Y}$ & $6 / 10$ \\
\hline Nan-yong Lee et al., 2015 ${ }^{10)}$ & $\mathrm{Y}$ & $\mathrm{Y}$ & $\mathrm{N}$ & $\mathrm{Y}$ & $\mathrm{N}$ & $\mathrm{N}$ & $\mathrm{N}$ & $\mathrm{Y}$ & $\mathrm{N}$ & $\mathrm{Y}$ & $\mathrm{Y}$ & $5 / 10$ \\
\hline Elisa Pelosin et al., 2010 29) & $\mathrm{Y}$ & $\mathrm{Y}$ & $\mathrm{N}$ & $\mathrm{Y}$ & $\mathrm{N}$ & $\mathrm{N}$ & $\mathrm{N}$ & $\mathrm{Y}$ & $\mathrm{N}$ & $\mathrm{Y}$ & $\mathrm{Y}$ & $6 / 10$ \\
\hline Atefeh Azarpaikan et al., 2014 30 ) & $\mathrm{Y}$ & $\mathrm{Y}$ & $\mathrm{Y}$ & $\mathrm{Y}$ & Y & $\mathrm{Y}$ & $\mathrm{Y}$ & $\mathrm{Y}$ & $\mathrm{Y}$ & Y & $\mathrm{Y}$ & 10 \\
\hline Giuzeppe Frazzitta et al., 2014 31 ) & $\mathrm{Y}$ & $\mathrm{Y}$ & $\mathrm{Y}$ & $\mathrm{Y}$ & $\mathrm{Y}$ & $\mathrm{Y}$ & $\mathrm{Y}$ & $\mathrm{Y}$ & $\mathrm{Y}$ & $\mathrm{Y}$ & $\mathrm{Y}$ & 10 \\
\hline Colleen G., Canning et al., 2014 32 ) & $\mathrm{Y}$ & $\mathrm{Y}$ & $\mathrm{Y}$ & $\mathrm{Y}$ & Y & $\mathrm{Y}$ & $\mathrm{Y}$ & $\mathrm{Y}$ & $\mathrm{Y}$ & Y & $\mathrm{Y}$ & $9 / 10$ \\
\hline Margaret Schenkman et al., 2012 33 ) & $\mathrm{Y}$ & $\mathrm{Y}$ & $\mathrm{Y}$ & $\mathrm{Y}$ & $\mathrm{N}$ & $\mathrm{Y}$ & $\mathrm{Y}$ & $\mathrm{Y}$ & $\mathrm{Y}$ & $\mathrm{Y}$ & $\mathrm{Y}$ & 10 \\
\hline Gustavo Christofoletti et al., 2010 & $\mathrm{Y}$ & $\mathrm{Y}$ & $\mathrm{Y}$ & $\mathrm{Y}$ & $\mathrm{N}$ & $\mathrm{N}$ & $\mathrm{Y}$ & $\mathrm{Y}$ & Y & $\mathrm{Y}$ & $\mathrm{Y}$ & $8 / 10$ \\
\hline Gao Qiang et al., 2014 35 ) & $\mathrm{Y}$ & $\mathrm{Y}$ & $\mathrm{Y}$ & $\mathrm{Y}$ & $\mathrm{N}$ & $\mathrm{N}$ & $\mathrm{Y}$ & $\mathrm{Y}$ & $\mathrm{Y}$ & $\mathrm{Y}$ & $\mathrm{Y}$ & $8 / 10$ \\
\hline Serene S Paulo et al., 2014 ${ }^{36)}$ & $\mathrm{Y}$ & $\mathrm{Y}$ & $\mathrm{Y}$ & $\mathrm{Y}$ & $\mathrm{Y}$ & $\mathrm{Y}$ & $\mathrm{Y}$ & $\mathrm{Y}$ & $\mathrm{Y}$ & $\mathrm{Y}$ & $\mathrm{Y}$ & 10 \\
\hline Xia Shen et al., 2012 37 ) & $\mathrm{Y}$ & $\mathrm{Y}$ & $\mathrm{Y}$ & $\mathrm{Y}$ & $\mathrm{N}$ & $\mathrm{N}$ & $\mathrm{Y}$ & $\mathrm{N}$ & $\mathrm{Y}$ & $\mathrm{Y}$ & Y & $7 / 10$ \\
\hline Ryan P., Duncan et al., 2012 38 ) & $\mathrm{Y}$ & Y & $\mathrm{Y}$ & $\mathrm{Y}$ & $\mathrm{N}$ & $\mathrm{N}$ & $\mathrm{Y}$ & $\mathrm{N}$ & $\mathrm{Y}$ & Y & $\mathrm{Y}$ & $7 / 10$ \\
\hline
\end{tabular}

Y: yes; N: no

provements in quality of life, are needed for individuals with Parkinson's. It is important for assessment methods to analyze functional changes in all stages of the disease and to be particularly sensitive in the evaluation of therapeutic interventions ${ }^{39}$.

Among the specific Parkinson's classification measures used in the studies analyzed, the UPDRS is a validated scale that provides an objective perspective and allows the classification of individuals with Parkinson's. The UPDRS is also widely used by physiotherapists for the evaluation of balance in clinical practice, as it has specific items for the assessment of this characteristic. The scale was found to be precise and sensitive according to the results of 14 articles analyzed in the present systematic review, the study populations of wich were subject to different intervention protocols ${ }^{40)}$. The scale was validated for the population with Parkinson's and, in contains items for the assessment of balance. Volpe et al. ${ }^{41)}$ conducted a study involving 24 patients with Parkinson's allocated to two groups and assessed balance using the UPDRS. Regarding the motor skills section of the scale, the authors found a significant improvement in the experimental group (dance) in comparison with the control group (conventional physical therapy).

Eleven studies included in the present review used the Berg Balance Scale for the assessment of balance. This scale is composed of 14 tasks that are common in daily living. Each item is scored from 0 to 4 points, with a maximum score of 56 
Table 2. Characteristics of the studies included in the present systematic review

\begin{tabular}{|c|c|c|c|}
\hline $\begin{array}{l}\text { Authors and year of } \\
\text { publication }\end{array}$ & Study design & Intervention & Outcomes \\
\hline \multirow{4}{*}{$\begin{array}{l}\text { Abud Qutubuddin } \\
\text { et al., 2013 }\end{array}$} & \multirow{4}{*}{ Clinical trial } & \multirow{4}{*}{ Forced exercise on stationary bike (EG) } & 1-UPDRS \\
\hline & & & 2-BBS \\
\hline & & & 3-Finger Taping Test \\
\hline & & & 4-PDQ-39 \\
\hline \multirow{4}{*}{$\begin{array}{l}\text { Sara Pires } \\
\text { et al., 2014 }\end{array}$} & \multirow{4}{*}{ Clinical trial } & \multirow{4}{*}{$\begin{array}{l}\text { Combination of musical auditory cues and regular } \\
\text { physical therapy }(\mathrm{EG}) \\
\text { Regular physical therapy alone }(\mathrm{CG})\end{array}$} & 1-UPDRS \\
\hline & & & 2-BBS \\
\hline & & & 3-TUG \\
\hline & & & 4-PDQ-39 \\
\hline \multirow{3}{*}{$\begin{array}{l}\text { Chirs J.Hass } \\
\text { et al., 2011 }\end{array}$} & \multirow{3}{*}{ Clinical trial } & \multirow{3}{*}{$\begin{array}{l}\text { PRT program (EG) } \\
\text { No intervention (CG) }\end{array}$} & 1-FRT \\
\hline & & & 2-TUG \\
\hline & & & 3-UPDRS \\
\hline \multirow{5}{*}{$\begin{array}{l}\text { Fuzhong Li } \\
\text { et al., 2012 } 20 \text { ) }\end{array}$} & \multirow{5}{*}{ Clinical trial } & \multirow{5}{*}{$\begin{array}{l}\text { Adapted Tai Chi program } \\
\text { Tree groups; Tai chi, resistance training, and stretch- } \\
\text { ing }\end{array}$} & 1-Isokinetic dynamometer \\
\hline & & & 2-GAITRite \\
\hline & & & 3-FRT \\
\hline & & & 4-UPRDS \\
\hline & & & 5-TUG \\
\hline \multirow{2}{*}{$\begin{array}{l}\text { Fuzhong Li } \\
\text { et al., } 2012^{20)}\end{array}$} & \multirow{2}{*}{ Clinical trial } & Technology-assisted balance and gait training (EG) & \multirow{2}{*}{ 1-Single-leg stance test } \\
\hline & & Strengthening exercises (CG) & \\
\hline \multirow{8}{*}{$\begin{array}{l}\text { Natalie E. Allen } \\
\text { et al., 2010 22) }\end{array}$} & \multirow{8}{*}{ Clinical trial } & \multirow{8}{*}{ Minimally supervised exercise program } & 1-Algorithm \\
\hline & & & 2-Coordinated stability test \\
\hline & & & 3-Sway meter \\
\hline & & & 4-BBS \\
\hline & & & 5-FOG Questionnaire \\
\hline & & & 6-SPPB \\
\hline & & & 7-Short -FES \\
\hline & & & 8-PDQ-39 \\
\hline \multirow{3}{*}{$\begin{array}{l}\text { Xian Shen } \\
\text { et al., 20148) }\end{array}$} & \multirow{3}{*}{ Clinical trial } & \multirow{3}{*}{$\begin{array}{l}\text { Balance and gait training with enhanced feedback } \\
(\mathrm{EG}) \\
\text { Lower limb strength training }(\mathrm{CG})\end{array}$} & $1-\mathrm{ABC}$ \\
\hline & & & 2-Limits-of-stability test \\
\hline & & & 3-Single-leg stance test \\
\hline \multirow{4}{*}{$\begin{array}{l}\text { C. Tassorelli } \\
\text { et al., 2014 } 24)\end{array}$} & & & 1-Kinematic analysis of movement \\
\hline & Clinis tria & Injection of botulinum toxin type $\mathrm{A}+$ intensive & 2-EMG \\
\hline & Clinical trial & $\begin{array}{l}\text { program (EG) } \\
\text { Saline solution + intensive program }(\mathrm{CG})\end{array}$ & 3-UPRDS \\
\hline & & & 4-VAS \\
\hline & & & 1-SF-12 \\
\hline Nima Toosizadeh & Clinical trial & Electroacupuncture (EG) & 2-Short-FES \\
\hline et al., 201425) & Clinical trial & Sham treatment $(\mathrm{CG})$ & 3-MMSE \\
\hline & & & 4-UPRS \\
\hline & & & 1-BBS \\
\hline Alessandro Picelli & Clinical tria & Robot-assisted treadmill training (EG) & $2-\mathrm{ABC}$ \\
\hline et al., 2012 26) & Clinical trial & Treadmill training alone $(\mathrm{CG})$ & 3-TUG \\
\hline & & & 4-10MWT \\
\hline & & & 1-BBS \\
\hline & & & $2-\mathrm{ABC}$ \\
\hline & & & 3-Postural transfer test \\
\hline Nicola Smania & Clinical tria & Balance training $(\mathrm{EG})$ & $4-\mathrm{COP}$ \\
\hline et al., $2010^{27)}$ & Clinical trial & General physical exercises (CG) & 5-UPRDS \\
\hline & & & 6-H\&Y \\
\hline & & & 7-Staging scale \\
\hline & & & 8-GDS \\
\hline
\end{tabular}


Table 2. Continued

\begin{tabular}{|c|c|c|c|}
\hline $\begin{array}{l}\text { Authors and year of } \\
\text { publication }\end{array}$ & Study design & Intervention & Outcomes \\
\hline $\begin{array}{l}\text { Mohan Ganesan } \\
\text { et al., 2013 }\end{array}$ & Clinical trial & $\begin{array}{l}\text { Tree groups: dopamine, } \\
\text { dopamine + conventional treadmill training, dopa- } \\
\text { mine + PWSTT }\end{array}$ & $\begin{array}{l}\text { 1-UPDRS } \\
\text { 2-Dynamic posturography } \\
\text { 3-BBS } \\
\text { 4-POMA }\end{array}$ \\
\hline $\begin{array}{l}\text { José Eduardo Pompeu } \\
\text { et al., 20129) }\end{array}$ & Clinical trial & $\begin{array}{l}\text { Training performed with } 10 \mathrm{Wii} \mathrm{Fit}^{\mathrm{TM}} \text { games (EG) } \\
\text { Balance exercises }(\mathrm{CG})\end{array}$ & 1-UPRS \\
\hline $\begin{array}{l}\text { Nam-Yong Lee } \\
\text { et al., 2015 }\end{array}$ & Clinical trial & $\begin{array}{l}\text { NDS + FES + Dance (EG) } \\
\text { NDS + FES }(\mathrm{CG})\end{array}$ & $\begin{array}{l}\text { 1-BBS } \\
\text { 2-Modified Barthel Index } \\
\text { 3-Beck Depression Inventory }\end{array}$ \\
\hline $\begin{array}{l}\text { Elisa Pelosin } \\
\text { et al., } 2010^{29)}\end{array}$ & Clinical trial & $\begin{array}{l}\text { Physical therapy + strategic video (EG) } \\
\text { Physical therapy + video of landscapes (CG) }\end{array}$ & 1-FOG Questionnaire \\
\hline $\begin{array}{l}\text { Atefeh Azarpaikan } \\
\text { et al., 2014 }\end{array}$ & Clinical trial & NFT training period & $\begin{array}{l}\text { 1-BBS } \\
\text { 2-ECG } \\
\text { 3-Isokinetic dynamometer }\end{array}$ \\
\hline $\begin{array}{l}\text { Giuzeppe Frazzitta } \\
\text { et al., 2014 }\end{array}$ & Clinical trial & $\begin{array}{l}\text { Intensive aerobic exercises (EG) } \\
\text { Non-intensive exercises (CG) }\end{array}$ & $\begin{array}{l}\text { 1-UPDRS } \\
\text { 2-BBS } \\
\text { 3-6WMT }\end{array}$ \\
\hline $\begin{array}{l}\text { Colleen G. Canning } \\
\text { et al., 2014 }\end{array}$ & Clinical trial & $\begin{array}{l}\text { Minimally supervised exercises -PD WEBB (EG) } \\
\text { Habitual care (CG) }\end{array}$ & $\begin{array}{l}\text { 1-Coordinated balance stability test } \\
\text { 2-FOG Questionnaire } \\
\text { 3-FES-I } \\
\text { 4-Physical Activity Questionnaire } \\
\text { 5-SF-12V2 } \\
\text { 6-SF-6D } \\
\text { 7-PDQ-39 }\end{array}$ \\
\hline $\begin{array}{l}\text { Margaret Schenkman } \\
\text { et al., 201233) }\end{array}$ & Clinical trial & $\begin{array}{l}\text { Supervised FBF and AE physical exercise program } \\
\text { (EG) } \\
\text { Conventional at-home physical exercise (CG) }\end{array}$ & $\begin{array}{l}\text { 1-CS-PFP } \\
\text { 2-FRT } \\
\text { 3-UPRDRS } \\
\text { 4-PDQ-39 } \\
\end{array}$ \\
\hline $\begin{array}{l}\text { Gustavo Christofoletti } \\
\text { et al., 2010 }\end{array}$ & Clinical trial & $\begin{array}{l}\text { Balance and motor function stimulation exercise } \\
\text { protocol (EG) }\end{array}$ & $\begin{array}{l}1-\mathrm{BBS} \\
2-\mathrm{TUG}\end{array}$ \\
\hline $\begin{array}{l}\text { Gao Qiang } \\
\text { et al., 2014 }\end{array}$ & Clinical trial & $\begin{array}{l}\text { Yang-style Tai Chi exercise protocol (EG) } \\
\text { No intervention (CG) }\end{array}$ & $\begin{array}{l}\text { 1-BBS } \\
\text { 2-TUG } \\
\text { 3-UPDRS }\end{array}$ \\
\hline $\begin{array}{l}\text { Serene S Paulo } \\
\text { et al., 2014 }\end{array}$ & Clinical trial & $\begin{array}{l}\text { Muscle strength training of legs with pneumatic } \\
\text { equipment }(E G) \\
\text { Simulated low-intensity exercise (CG) }\end{array}$ & $\begin{array}{l}\text { 1-Muscle strength } \\
\text { 2-10MWT } \\
\text { 3-TUG } \\
\text { 4- Single-leg stance test }\end{array}$ \\
\hline $\begin{array}{l}\text { Xia Shen } \\
\text { et al., 2012 }\end{array}$ & Clinical trial & $\begin{array}{l}\text { Training with repetitive steps on preparatory visual } \\
\text { tracks (EG) } \\
\text { UM-detook (CG) }\end{array}$ & $\begin{array}{l}\text { 1-UPRDS } \\
\text { 2-Limits-of-stability test } \\
\text { 3-GAITRite }\end{array}$ \\
\hline $\begin{array}{l}\text { Ryan P. Duncan } \\
\text { et al., 2012 }\end{array}$ & Clinical trial & $\begin{array}{l}\text { Tango dance program (EG) } \\
\text { No intervention }(C G)\end{array}$ & $\begin{array}{l}\text { 1-UPRDS } \\
\text { 2- Mini BESTest } \\
\text { 3-FOG Questionnaire } \\
\text { 4-6WMT } \\
\text { 5-9HPT } \\
\text { 6-GAITRite }\end{array}$ \\
\hline
\end{tabular}


points. The points are based on the time for which a position is held, the distance to which the upper limb is capable of reaching out in front of the body, and the time required to complete each task ${ }^{42}$. This is a fast, precise assessment tool for detecting changes in balance among individuals with Parkinson's. In a previous systematic review with meta-analysis, Chih-Hsuan Chou et al. ${ }^{43)}$ found that a reduction in the gait velocity score on the Berg Balance Scale was correlated with impairment regarding the performance of activities of daily living.

The Timed Up and Go Test is used to quantify functional mobility based on the time (in seconds) required to perform the task of standing up from a chair (seat approximately 46 in height and armrests $65 \mathrm{~cm}$ in height), walking three meters, turning around, returning to the chair, and sitting down again ${ }^{42}$. This measure has a specific relationship with gait speed and functional mobility. In the population studied, the Timed Up and Go Test is a good predictor of the risk of falls. Although it was not specifically designed for the assessment of balance, the importance of this measure to the evaluation of dynamic balance related to mobility was evident in the studies analyzed in the present review. In a systematic review with meta-analysis involving 53 studies, Schoene et al. ${ }^{44)}$ found that the Timed Up and Go Test was a sensitive assessment tool for the evaluation of gait stability and balance in more than $50 \%$ of the studies, which is in agreement with the findings of the present systematic review.

A large portion of the studies employed three or more assessment tools, which were always accompanied by tests and equipment. Several studies have addressed the use of assessment measures for the evaluation of balance among individuals with Parkinson's with the aim of designing interventions that favor an improvement in quality of life and a reduction in the risk of falls. Thus, the studies analyzed evaluated individuals in a complex fashion with functional approaches that were adaptable to the needs of such patients.

The present review shows that a variety of different assessment tools are used for the evaluation of balance in patients with Parkinson's disease, such as scales, tests, and equipment. The majority of studies employed more than one measure, and there is no consensus regarding a single, precise assessment tool for the evaluation of balance in this population.

\section{ACKNOWLEDGEMENT}

The authors gratefully acknowledge financial support from the Brazilian National Council for Scientific and Technological Development (CNPq).

\section{REFERENCES}

1) Uhrbrand A, Stenager E, Pedersen MS, et al.: Parkinson's disease and intensive exercise therapy — a systematic review and meta-analysis of randomized controlled trials. J Neurol Sci, 2015, 353: 9-19. [Medline] [CrossRef]

2) King LA, Priest KC, Nutt J, et al.: Comorbidity and functional mobility in people with Parkinson's disease. PM R, 2014, 94: 2152-2157.

3) Lenka A, Jhunjhunwala KR, Saini J, et al.: Structural and functional neuroimaging in patients with Parkinson's disease and visual hallucinations: a critical review. Parkinsonism Relat Disord, 2015, 21: 683-691. [Medline] [CrossRef]

4) Yogev-Seligmann G, Giladi N, Gruendlinger L, et al.: The contribution of postural control and bilateral coordination to the impact of dual tasking on gait. Exp Brain Res, 2013, 226: 81-93. [Medline] [CrossRef]

5) Conradsson D, Lofreguen N, Stahlea A, et al.: The conceptual framework of the novel to balance training in Parkinson's disease study protocol fartor a randomized controlled trial. BMC Neurol, 2012, 12: 111.

6) Takeuti T, Maki T, Silva CV, et al.: Correlation between balance and incidence of falls in patients with Parkinson's disease. Neurocienc, $2011,19: 237-243$.

7) Abe PT, Vitorino DF, Guimarães LH, et al.: Análise do equilíbrio nos pacientes com doença de Parkinson grau leve e moderado através da fotogrametria. Neurocienc, 2004, 12: 2 .

8) Shen X, Mak MK: Balance and gait training with augmented feedback improves balance confidence in people with Parkinson's disease: a randomized controlled trial. Neurorehabil Neural Repair, 2014, 28: 524-535. [Medline] [CrossRef]

9) Pompeu JE, Mendes FA, Silva KG, et al.: Effect of Nintendo WiiTM-based motor and cognitive training on activities of daily living in patients with Parkinson's disease: a randomised clinical trial. Physiotherapy, 2012, 98: 196-204. [Medline] [CrossRef]

10) Lee NY, Lee DK, Song HS: Effect of virtual reality dance exercise on the balance, activities of daily living, and depressive disorder status of Parkinson's disease patients. J Phys Ther Sci, 2015, 27: 145-147. [Medline] [CrossRef]

11) Song CS: Intrarater reliability of action research arm test for individuals with Parkinson's disease. J Phys Ther Sci, 2012, 24: 1355-1357. [CrossRef]

12) Sampaio RF, Mancini MC, Fonseca ST: Produção científica e atuação profissional: aspectos que limitam essa integração na fisioterapia e na terapia ocupacional. Rev Bras Fisioter, 2002, 6: 3.

13) Cholewa J, Gorzkowska A, Szepelawy M, et al.: Influence of functional movement rehabilitation on quality of life in people with Parkinson's disease. J Phys Ther Sci, 2014, 26: 1329-1331. [Medline] [CrossRef]

14) Bennie S, Bruner K, Dizon A, et al.: Measurements of balance: comparison of the timed 'Up and Go' test reach test with the Berg Balance Scale. J Phys Ther Sci, 2003, 15: 93-97. [CrossRef]

15) Henmi O, Shiba Y, Saito T, et al.: Spectral analysis of gait variability of stride interval time series: comparison of young, elderly and Parkinson's disease patients. J Phys Ther Sci, 2009, 21: 105-111. [CrossRef]

16) Han J, Jung J, Lee J, et al.: Effect of muscle vibration on postural balance of Parkinson's diseases patients in bipedal quiet standing. J Phys Ther Sci, 2013, 25: 
1433-1435. [Medline] [CrossRef]

17) Qutubuddin A, Reis T, Alramadhani R, et al.: Parkinson's disease and forced exercise: a preliminary study. Rehabil Res Pract, 2013, 2013: 375267. [Medline]

18) Pires S, Festas MJ, Soares T, et al.: Pistas auditivas musicais na fisioterapia em grupo de doentes com Parkinson. Investigação original, $2014,28: 162-166$.

19) Hass CJ, Buckley TA, Pitsikoulis C, et al.: Progressive resistance training improves gait initiation in individuals with Parkinson's disease. Gait Posture, 2012, 35: 669-673. [Medline] [CrossRef]

20) Li F, Harmer P, Fitzgerald K, et al.: Tai chi and postural stability in patients with Parkinson's disease. N Engl J Med, 2012, 366: 511-519. [Medline] [CrossRef]

21) Shen X, Mak MK: Technology-assisted balance and gait training reduces falls in patients with Parkinson's disease: a randomized controlled trial with 12-month follow-up. Neurorehabil Neural Repair, 2015, 29: 103-111. [Medline] [CrossRef]

22) Allen NE, Canning CG, Sherrington C, et al.: The effects of an exercise program on fall risk factors in people with Parkinson's disease: a randomized controlled trial. Mov Disord, 2010, 25: 1217-1225. [Medline] [CrossRef]

23) Stack E, Roberts H, Ashburn A: The PIT: SToPP Trial—A Feasibility Randomised Controlled Trial of Home-Based Physiotherapy for People with Parkinson's Disease Using Video-Based Measures to Preserve Assessor Blinding. Parkinson Disorders, 2012.

24) Tassorelli C, De Icco R, Alfonsi E, et al.: Botulinum toxin type A potentiates the effect of neuromotor rehabilitation of Pisa syndrome in Parkinson disease: a placebo controlled study. Parkinsonism Relat Disord, 2014, 20: 1140-1144. [Medline] [CrossRef]

25) Toosizadeh N, Lei H, Schwenk M, et al.: Does integrative medicine enhance balance in aging adults? Proof of concept for the benefit of electroacupuncture therapy in Parkinson's disease. Gerontology, 2015, 61: 3-14. [Medline] [CrossRef]

26) Picelli A, Melotti C, Origano F, et al.: Does robotic gait training improve balance in Parkinson's disease? A randomized controlled trial. Parkinsonism Relat Disord, 2012, 18: 990-993. [Medline] [CrossRef]

27) Smania N, Corato E, Tinazzi M, et al.: Effect of balance training on postural instability in patients with idiopathic Parkinson's disease. Neurorehabil Neural Repair, 2010, 24: 826-834. [Medline] [CrossRef]

28) Ganesan M, Sathyaprabha TN, Gupta A, et al.: Effect partial weight supported treadmill gait train balance patients Parkinson. Dis Am Acad Phys Med Rehabil, 2014, 6: 22-33.

29) Pelosin E, Avanzino L, Bove M, et al.: Action observation improves freezing of gait in patients with Parkinson's disease. Neurorehabil Neural Repair, 2010, 24: 746-752. [Medline] [CrossRef]

30) Azarpaikan A, Torbati HT, Sohrabi M: Neurofeedback and physical balance in Parkinson's patients. Gait Posture, 2014, 40: 177-181. [Medline] [CrossRef]

31) Frazzitta G, Maestri R, Ghilardi MF, et al.: Intensive rehabilitation increases BDNF serum levels in parkinsonian patients: a randomized study. Neurorehabil Neural Repair, 2014, 28: 163-168. [Medline] [CrossRef]

32) Canning CG, Sherrington C, Lord SR, et al.: Exercise for falls prevention in Parkinson disease: a randomized controlled trial. Neurology, 2015 , 84: 304-312.

33) Schenkman M, Hall DA, Barón AE, et al.: Exercise for people in early- or mid-stage Parkinson disease: a 16-month randomized controlled trial. Phys Ther, 2012, 92: 1395-1410. [Medline] [CrossRef]

34) Christofoletti G, Freitas RT, Candido ER, et al.: Effectiveness of a physical therapy treatment on static and dynamic balance of subjects with Parkinson's disease. Fisioterapia Pesquisa, 2010, 17: 259-263. [CrossRef]

35) Gao Q, Leung A, Yang Y, et al.: Effects of Tai Chi on balance and fall prevention in Parkinson's disease: a randomized controlled trial. Clin Rehabil, 2014, 28: 748-753. [Medline] [CrossRef]

36) Paul SS, Canning CG, Song J, et al.: Leg muscle power is enhanced by training in people with Parkinson's disease: a randomized controlled trial. Clin Rehabil, 2014, 28: 275-288. [Medline] [CrossRef]

37) Shen X, Mak MK: Repetitive step training with preparatory signals improves stability limits in patients with Parkinson's disease. J Rehabil Med, 2012, 44: 944-949. [Medline] [CrossRef]

38) Duncan RP, Earhart GM: Randomized controlled trial of community-based dancing to modify disease progression in Parkinson disease. Neurorehabil Neural Repair, 2012, 26: 132-143. [Medline] [CrossRef]

39) Horta W: Escalas clínicas para avaliação de pacientes com doença de parkinson. In: Meneses Ms, Teive HAG. Doença de Parkinson: aspectos clínicos e cirúrgicos. Rio de Janeiro Guanabara Koogan, 1996, pp 83-96.

40) Schenkman ML, Clark K, Xie T, et al.: Spinal movement and performance of a standing reach task in participants with and without Parkinson disease. Phys Ther, 2001, 81: 1400-1411. [Medline]

41) Volpe D, Signorini M, Marchetto A, et al.: A comparison of Irish set dancing and exercises for people with Parkinson's disease: a phase II feasibility study. BMC Geriatr, 2013, 13: 54. [Medline] [CrossRef]

42) Karuka AH, Silva JA, Navega MT: Analysis of agreement of assessment tools of body balance in the elderly. Rev Bras Fisioter, 2011, 15: 460-466. [Medline] [CrossRef]

43) Chou CH, Hwang CL, Wu YT: Effect of exercise on physical function, daily living activities, and quality of life in the frail older adults: a meta-analysis. Arch Phys Med Rehabil, 2012, 93: 237-244. [Medline] [CrossRef]

44) Schoene D, Wu SM, Mikolaizak AS, et al.: Discriminative ability and predictive validity of the timed up and go test in identifying older people who fall: systematic review and meta-analysis. J Am Geriatr Soc, 2013, 61: 202-208. [Medline] [CrossRef] 